\title{
Pracovní skupina srdeční selhání na XVIII. výročním sjezdu ČKS 2010
}

Pracovní skupina srdeční selhání se aktivně podílela na odborném programu letošního sjezdu ČKS a připravila několik bloků př̀ednášek.

Blok Př́spěvek kardiochirurga k léčbě srdečního selhání připravila pracovní skupina ve spolupráci s IKEM Praha a Centrem kardiovaskulární a transplantační chirurgie Brno. Prof. Pirk z Prahy se ve své přednášce zabýval chirurgickou revaskularizací myokardu u nemocných s těžkou dysfunkcí levé komory. Přednesl výsledky studie STICH II, které srovnávaly u ischemických pacientů s dysfunkcí levé komory klasickou operaci pomocí bypassů s postupem kombinujícím bypassy a současnou chirurgickou reparaci komory. Výsledky ukázaly, že ani v symptomatologii, ani v kvalitě života či přežívání nepřinesla rozšiřrená chirurgická intervence další prospěch. Naopak zvýšila náklady na pacienta a prodloužila dobu trvání operace. Doc. Němec z Brna ve své přednášce posoudil možnosti operace na chlopních u pacientů s dysfunkcí levé komory. Do řešení několika konkrétních př́padů nemocných zapojil i auditorium, aby se rozhodlo vždy pro jednu z možností: konzervativní postup, klasickou operaci či transplantaci. Rozhodování není jednoduché, a jak vyplynulo z jednotlivých případů, musí být vždy individuální. Doc. Málek z Prahy ve své přednášce srovnával možnost revaskularizace se srdeční transplantací u pacientů s pokročilou dysfunkcí levé komory. Pokud lze provést revaskularizaci a zvláště v př́tomnosti viabilního myokardu, by tato metoda měla mít přednost před transplantací, která je až posledním řešením srdečního selhání. Novou možností, která umožňuje pacientům na čekací listině na srdeční transplantaci se v lepším stavu dožít vlastní operace, jsou mechanické podpory oběhu. Doc. Netuka z Prahy nejprve přehledně ukázal jejich typy a rozdělení a následně vlastní sedmileté zkušenosti z IKEM. Výsledky jsou povzbudivé, protože i přes větší riziko krvácení či infekce, vedou mechanické podpory ke zlepšení hemodynamického stavu pacienta. V poslední přednášce se MUDr. Malý z Prahy zabýval mechanickými srdečními podporami jako destinační terapií léčby pokročilého srdečního selhání. Uvedl zde zejména výsledky nové studie REMATCH II, která porovnala dva typy srdečních podpor: pulsatilní a kontinuální. V obou případech bylo přežívání pacientů výrazně lepší než ve studii REMATCH I, která měla ještě srovnání s větví léčenou pouze medikamentózně. Destinační terapie by tak do budoucna mohla představovat alternativu pro pacienty, kteři již nesplňují kritéria indikace k srdeční transplantaci.

Další blok s názvem Kardiální kachexie a metabolický syndrom připravila Pracovní skupina srdeční selhání ve spolupráci s IKEM Praha, Interní kardiologickou klinikou FN Brno a Cardiovascular Division, Mayo Clinic, Rochester, USA. MUDr. Hegarová $z$ IKEM se ve své přednášce podrobně věnovala patofyziologii kardiální kachexie, zejména některým novým působkům, které hrají důležitou roli u tohoto syndromu. Taktéž poukázala na klinický význam syndromu kardiální kachexie, zejména na velmi špatnou prognózu těchto nemocných. Na tuto přednášku navázal MUDr. Wiendl taktéž z IKEM přednáškou na téma léčebný př́stup $\mathrm{k}$ nemocným $\mathrm{s}$ pokročilým srdečním selháním a projevy kachexie. Ve svém sdělení kladl důraz na dostatečnou výživu nemocných se srdečním selháním a rovněž na jejich pohybovou aktivitu. Na závěr přednášky se diskutovalo i o možnosti ovlivnění některých působků, které se uplatňují v patofyziologii kardiální kachexie, zejména ghrelinu. Poslední přednášku přednesl MUDr. Konečný z Mayo Clinic v USA. Jeho sdělení se týkalo výskytu metabolického syndromu u nemocných se srdečním selháním. Poukázal na vysokou prevalenci metabolického syndromu a taktéž na vysokou morbiditu a mortalitu těchto nemocných, zejména ve vyspělých státech světa.

Blok věnovaný reverzibilním príčinám chronického srdečního selhání aneb poučení z kasuistik zahájil prof. Hradec problematikou anemie u srdečního selhání. Anemie je zejména v pokročilejších stadiích srdečního selhání poměrně častá a je nezávislým prediktorem nepříznivé prognózy. Ve druhé části přehledně shrnul výsledky pilotních klinických studií, které ukázaly zlepšení symptomatologie při léčbě rekombinačním erytropoetinem u pacientů s chronickým srdečním selháním. Definitivní zhodnocení se očekává od probíhající klinické studie RED-HF. MUDr. Kubánek pronesl přednášku o problematice těhotenské kardiomyopatie. Pro onemocnění je typický reverzibilní průběh srdečního selhání. $\mathrm{V}$ posledních letech se řada autorů přiklání $\mathrm{k}$ rozšíření časového rámce pro diagnózu těhotenské kardiomyopatie na 17.-40. týden těhotenství a pět až šest měsíců po porodu. Pokroky v léčbě srdečního selhání s možností implantace mechanické srdeční podpory vedou u kriticky nemocných ke zlepšení prognózy onemocnění. Prof. Elbl se věnoval problematice kardiotoxicity cytostatik. V praxi se nejčastěji setkáváme $s$ tímto nežádoucím účinkem při léčbě antracykliny, s kardiotoxicitou je však třeba počítat také u některých novějších př́pravků, jako jsou trastuzumab, lapatinib a taxany. Autor přednášky zdůraznil nutnost echokardiografického screeningu u nemocných léčených těmito přípravky a potřebu časného zahájení léčby srdečního selhání při záchytu systolické dysfunkce. Důležitý je individuální přístup a úzká spolupráce onkologa s kardiologem. MUDr. Hošková se ve své přednášce zabývala problematikou dyssynchronie u pacientů se srdečním selháním. Na př́kladu nemocné s dilatační kardiomyopatií ukázala dlouhodobý příznivý vliv resynchronizační léčby. Šlo o pacientku s normalizací systolické funkce levé komory po implantaci biventrikulárního kardiostimulátoru. Randomizované studie prokázaly snížení počtu hospitalizací pro srdeční selhání a zlepšení prognózy nemocných. Hledají se kritéria, která by dokázala předpovědět dlouhodobý účinek resynchronizační léčby u konkrétního pacienta.

Závěrečný blok byl na téma Jak na to u srdečního selhání. Jako první přednášel prof. Špinar o akutním srdečním selhání a akutním infarktu myokardu a rozebral jím organizovaný národní registr akutního srdečního selhání AHEAD. Uvedl rozdíly úmrtnosti na akutní srdeční selhání de novo a při akut- 
ním infarktu myokardu, z mnoha zajímavých výsledků uvedl např̀ reverzibilní vztah úmrtí a krevního tlaku, hmotnosti či koncentrace cholesterolu. Prof. Špinarová rozebrala chronické srdeční selhání a akutní infarkt myokardu, vliv léčby od podávání vyšších dávek inhibitorů ACE či sartanů, zmínila studii CAPRICORN s carvedilolem, studii CORONA, kde význam podávání rosuvastatinu byl pouze u nemocných s nízkým NT-proBNP. Nakonec se věnovala přehledu úspěchů srdeční transplantace v ČR. Poslední přednášku měl prof. Vítovec o současném výskytu CHOPN a srdečního selhání, kde uvedl mimo jiné problematiku léčby beta-mimetiky a beta-blokátory u obou onemocnění.

Jiři Vítovec,

Lenka Špinarová,

Lenka Hošková,

Ondřej Ludka,

za Pracovní skupinu srdeční selhání
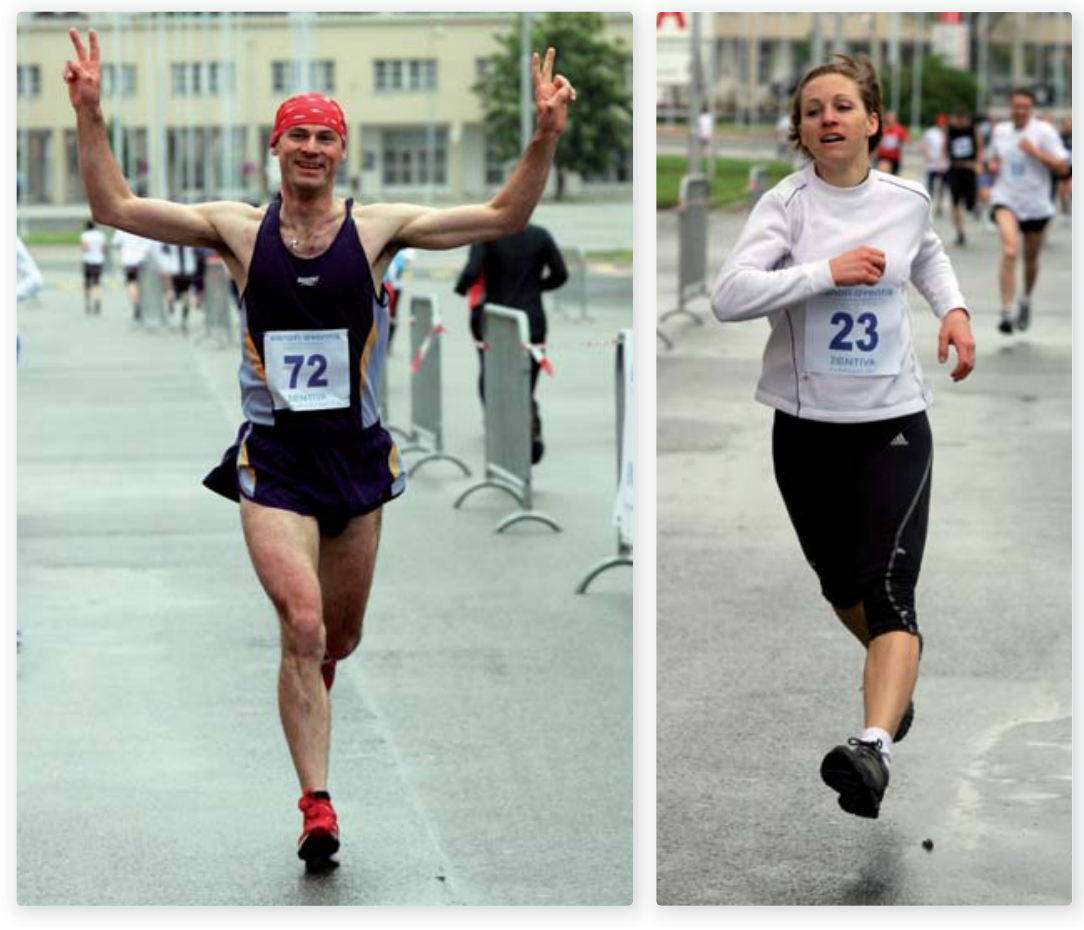

Kardioběh

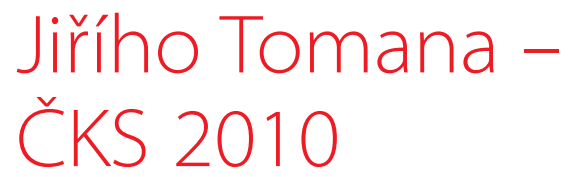

V rámci XVIII. výročního sjezdu České kardiologické společnosti se uskutečnil již 7. ročník Kardioběhu Jiřího Tomana. Běh se konal 18. 5. $2010 \mathrm{v}$ areálu BVV, sponzorován byl firmami Sanofi-Aventis a Zentiva, zajištěn firmou Galant a měřil $3000 \mathrm{~m}$. Jako každoročně jej odstartoval v 6.45 ráno známý sportovní komentátor Štěpán Škorpil. Bylo nesmírně potěšující, že se v ranním pošmourném počasí na trat vydalo rekordních 111 běžců, (77 mužů a 34 žen), mezi nimiž nechyběli tradičně prof. J. Pirk, přednosta kardiochirurgie IKEM, prof. M. Aschermann, místopredseda ČKS, i autor této zprávy, všichni již po sedmé. Absolutním vítězem se stal tradičně Petr Pospíšil (vlevo) v čase 8 min 56 s, druhý byl Ondřej Ošmera a třetí Pavel Něnička. V kategorii žen letos zvítězila Kateřina Simoneová (vpravo) $\mathrm{v}$ čase 10 min $13 \mathrm{~s}$, druhá byla Darina Krausová a třetí Petra Kofronová.

Protože bylo organizátorům vyčítáno, že nebyli vyhlášeni vítězové jednotlivých věkových kategorií, alespoň touto cestou jim gratulujeme: Ivo Varvařovskému v kategorii 40-45 let; Pavlu Něničkovi v kategorii 46-50 let; Františku Padourovi v kategorii 51-55 let; Jiřímu Slavíkovi 56-60 let a prof. Pirkovi v kategorii nad 61 let. V ženách (věkové kategorie galantně neuvádím): Darině Krausové; Andree Trčkové; Jarmile Smolíkové a Jarmile Božkové.

Všichni aktivní běžci obdrželi drobné dárky od sponzora a první tři v kategorii žen a mužů byly odměněni na Galavečeru ČKS krásnými soškami běžců. Jak řekl na závěr předání cen prof. Aschermann, organizátoři prríštího 8. kardioběhu Jiřího Tomana zařadí také kategorii Kardiochůze a věří, že účast bude opět hojná dle olympijského hesla „Není důležité zvítězit, je důležité zúčastnit se“.

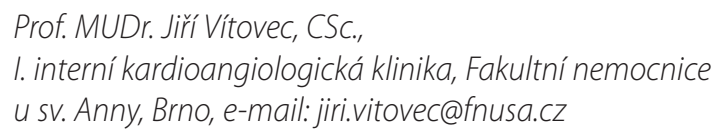

